\title{
Long-Term Assessment of an Innovative Mangrove Rehabilitation Project: Case Study on Carey Island, Malaysia
}

\author{
Shervin Motamedi, ${ }^{1}$ Roslan Hashim, ${ }^{2}$ Rozainah Zakaria, ${ }^{3}$ Ki-II Song, ${ }^{4}$ and Bakrin Sofawi ${ }^{3}$ \\ ${ }^{1}$ Department of Civil Engineering, Faculty of Engineering, University of Malaya, 50603 Kuala Lumpur, Malaysia \\ ${ }^{2}$ Institute of Ocean and Earth Sciences (IOES), University of Malaya, 50603 Kuala Lumpur, Malaysia \\ ${ }^{3}$ Institute of Biological Sciences, Faculty of Sciences, University of Malaya, 50603 Kuala Lumpur, Malaysia \\ ${ }^{4}$ Department of Civil Engineering, Inha University, 100 Inha-ro, Nam-gu, Incheon 402-751, Republic of Korea
}

Correspondence should be addressed to Roslan Hashim; roslan@um.edu.my

Received 17 April 2014; Revised 12 June 2014; Accepted 12 June 2014; Published 3 July 2014

Academic Editor: Ashok Kumar Gupta

Copyright (C) 2014 Shervin Motamedi et al. This is an open access article distributed under the Creative Commons Attribution License, which permits unrestricted use, distribution, and reproduction in any medium, provided the original work is properly cited.

\begin{abstract}
Wave energy and storm surges threaten coastal ecology and nearshore infrastructures. Although coastal structures are conventionally constructed to dampen the wave energy, they introduce tremendous damage to the ecology of the coast. To minimize environmental impact, ecofriendly coastal protection schemes should be introduced. In this paper, we discuss an example of an innovative mangrove rehabilitation attempt to restore the endangered mangroves on Carey Island, Malaysia. A submerged detached breakwater system was constructed to dampen the energy of wave and trap the sediments behind the structure. Further, a large number of mangrove seedlings were planted using different techniques. Further, we assess the possibility of success for a future mangrove rehabilitation project at the site in the context of sedimentology, bathymetry, and hydrogeochemistry. The assessment showed an increase in the amount of silt and clay, and the seabed was noticeably elevated. The nutrient concentration, the $\mathrm{pH}$ value, and the salinity index demonstrate that the site is conducive in establishing mangrove seedlings. As a result, we conclude that the site is now ready for attempts to rehabilitate the lost mangrove forest.
\end{abstract}

\section{Introduction}

Storm waves and erosion damage coastal environments and hurricanes inundate and destroy coastal properties [1]. Storms also cause severe short-term erosion, that is, more intensive than that caused by seasonal fluctuations [2]. Coastal zones need proper protection from these threats. Shoreline protection techniques should in fact prevent potential damages and restore erosion imbalances originating from natural or anthropogenic causes [3]. An understanding of effective protective mechanisms and their implementation is essential for maintaining and preserving natural elements near the shores [4-7].

Human interference has a direct and consistent influence on coasts $[8,9]$. Natural resources can be lost when artificial structures are installed. Steel and concrete have been used to construct coastal structures without considering the ecological imbalances that they might cause [10,11]. Artificialization near the coast, then, should be minimized to the extent possible.

Rigid one-directional approaches cannot fully encapsulate the needs of prediction of coastal systems [12-15]. Therefore, rigid approaches should be coupled with ecological engineering to deal with the consistent loss of ecosystem elements caused by artificialization. The concept of ecological engineering was introduced 30 years ago [16]. The concept of incorporating ecoengineering with coastal protection, however, has developed more recently.

The loss of mangrove forests in the last two decades is a unique example of human intervention in a coastal system $[9,17]$. Mangrove forests have been destroyed for industrial and agricultural purposes, timber and charcoal production, and shrimp farming. If the current decline rate persists, mangrove forests will vanish entirely in the next 100 years [18]. For example, Sungai Haji Durani in Selangor, Malaysia, suffered from excessive mangrove losses before ecocoastal 
protection was put in place. With the help of ecotechnologies, the site has been restored to a significant shelter for fauna and flora $[19,20]$.

In this paper, we briefly review the global threats to mangrove forests. Next, we discuss the potency of reestablishment for a dominant mangrove species (Avicennia marina) from engineering perspective. Finally, we introduce an innovative shoreline protection scheme for Carey Island in Selangor, Malaysia, in which a breakwater system is integrated with mangrove rehabilitation. We used various postassessment methods such as sedimentologic characterization of the coast, cross-section profiling, hydrogeochemical analysis of the soil and water, and cost estimation to characterize the shoreline of Carey Island for future mangrove rehabilitation projects.

\section{Threats to Mangrove Forests}

Mangroves are defined as individual plants in a mangrove forest community [21]. Ghazali [22] defined mangroves as plants existing in muddy, high-moisture soils of tropical and subtropical tidal waters. Mangrove forests grow only in accumulative forests situated at the verge of land and sea in tropical and subtropical latitudes between $25^{\circ} \mathrm{N}$ and $25^{\circ} \mathrm{S}$ [23]. They also grow naturally in sheltered coastal zones and on islands with locally variable topography and hydrology [24]. The forests consist of wide and unique varieties of vegetation that can grow despite exposure to wave impacts and water salinity in the harsh coastal environment.

The importance of mangroves is well documented in the literature [25-27]. Mangroves are renowned for their high biological productivity and nutrient source. For example, mangroves provide a suitable environment for breeding and serve as a nursery ground for marine species such as fish and terrestrial vertebrates [28]. In addition, the mangrove roots are capable of absorbing wave energy, which means that they can stabilize shoreline erosion and act as a natural barrier to protect the shoreline from devastating wave impacts generated by tsunamis and other storms [29]. For example, Duarte et al. [30] stated that tall mangrove trees are capable of significantly reducing wave energy.

A recent study estimated that the total mangrove forest area in 2005 was $137,760 \mathrm{~km}^{2}$ in 118 countries and territories in tropical and subtropical zones [23]. The authors stated that the largest extent of mangrove forest is found in Asia (42\%), followed by Africa (20\%), North and Central America (15\%), Oceania (12\%), and South America (11\%). Alongi [31] wrote that the most diverse biogeographical mangrove forests are in the Indo-Pacific region with Indonesia, Australia, Brazil, and Nigeria.

Recently, rapid growth in population, industrialization, and urbanization has diminished the mangrove forests [30]. Based on the most recent assessment which assessed the trends of mangrove loss between 1980 and 2005, the global existing forests have disappeared at annual rate of over $2 \%$ [32]. For example, in Malaysia, Ghazali [22] claimed that approximately $160 \mathrm{~km}^{2}$ of mangrove forests vanished each year from 1980 to 2001. As a result, mangrove restoration project is now an outstanding issue for shoreline protection.
2.1. Avicennia Marina: A Representative Mangrove Species in Peninsular Malaysia. Most of the western coastline in Peninsular Malaysia is fringed with mangrove forests in mud flats. The island of Sumatra in Indonesia shelters the seas in the Strait of Malacca, bringing a relative calmness to the seas in the western peninsula compared to eastern Malaysia, which faces the South China Sea. Alluvial plains are a common feature of the coasts on the western peninsula [29]. The rivers discharging to the straits on the west coasts carry mostly fine silt and clay that contribute to alluvial plain formation. The clayey deposits on the western coast of Malaysia provide a proper substrate for Avicennia marina mangroves, that is, conducive to their viability [20]. Therefore, the pioneer species of mangrove in Peninsular Malaysia is Avicennia marina, which propagates through seeding [22].

If the waters are relatively calm and the geotechnical stratum is well elevated with respect to mean sea level (MSL), Avicennia marina can take root [33]. When Avicennia marina forests grow to a certain height, the forests attenuate waves [34]. Wave attenuation leads to faster sediment deposition behind the mangrove forests $[32,35]$. Increases in the levels of sediments behind the trees block the ebb flow of the tide $[36,37]$. As a natural pond is forming, rainwater and the fresh water coming from upstream decrease the salinity of the pond. Avicennia marina cannot survive in a constant inundation of diluted saline water [33] and eventually dies. In addition, new seeds cannot grow in the target area because they cannot reach the ground, remaining afloat in the water. This process can be accelerated by the significant rise of the MSL.

\section{Materials and Methods}

Carey Island is located in the Banting district in Selangor, Malaysia. A mangrove replantation project was performed in the target area between 2008 and 2010. Evaluating the success of mangrove rehabilitation requires three to five years [19], so it is now time to evaluate the project. In the case study described here, we assess the current condition of Carey Island in terms of sedimentologic characteristics, hydrogeochemical aspects of soil and water, and topographical features of the associated beaches. We also assess the feasibility of future mangrove rehabilitation projects at the target site.

\subsection{Description of Site at Carey Island, Malaysia}

3.1.1. Geographical Location. Carey Island is located within the Klang Isle $\left(03^{\circ} 38^{\prime} \mathrm{N}\right.$ and $\left.101^{\circ} 00^{\prime} \mathrm{E}\right)$, which is one of the most famous mangrove forest reserves in the Strait of Malacca alongside the west coast of the Malaysia Peninsula (see Figure 1). Klang Isle is composed of eight small islets, and Carey Island is the largest of the islets, separated from the Selangor coast by the Langat River on the east and the Klang River on the north. The total area of Carey Island is $161.87 \mathrm{~km}^{2}$ and nearly $65 \%$ of its total area is covered with palm oil trees [38]. The island's elevation is lower than the mean high tide level. Consequently, to protect the upper land from the effect 


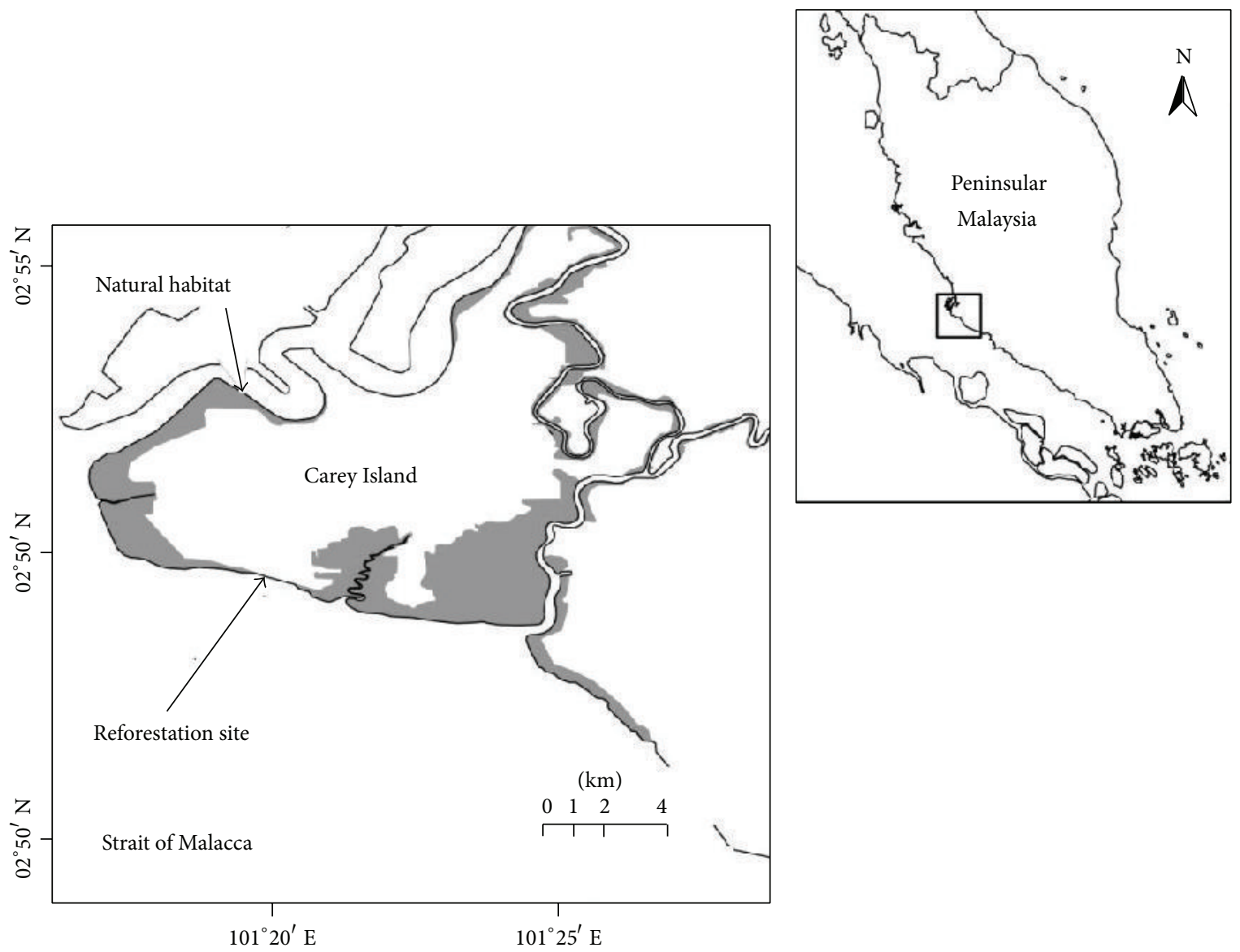

FIGURE 1: The geographical position of Carey Island. Gray-shaded hatch denotes the thin mangrove cover.

of higher waves, coastal dikes, a network of drainage canals, and water control systems have been constructed [26].

3.1.2. Geology and Sediment Stratigraphy. Carey Island is located next to the wider channel of the Strait of Malacca. Previous geological studies at Carey Island demonstrated the existence of alluvial textures [39-41]. Bathymetry studies in the Strait of Malacca reveal complicated characteristics, and the area has been interpreted as a "Pleistocene lowered-sealevel alluvial-delta-fan" system [42].

Approximately $70 \%$ of Carey Island is composed of Holocene deposits of clay, silty clay, peat, and minor sand formations that overplaced on Pleistocene deposits of gravel, sand, clay, and silt $[38,40]$. Sedimentary rocks comprise the underlying bedrock at the site. The bedrock is similar to that found in Selangor, Malaysia. Therefore, the bedrock at the Carey Island mainly constituted of interbedded shale, siltstone, and sandstone [43].

3.1.3. Climatic Properties. Tropical climate characteristics are widely found within the target site, and the climatic properties in this zone are tied to northeast and southwest monsoonal flows. During the intermonsoon season, the weather is highly unpredictable [20]. 


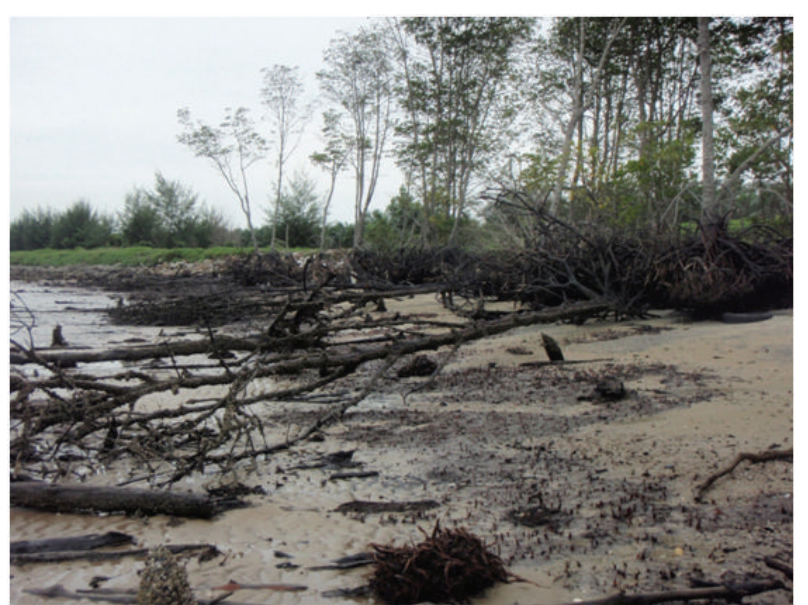

FIGURE 2: Loss of "Rhizophora apiculata" mangrove forests at the site before the project is carried out in early 2008 .

wave energy induced by storms [20]. The environmental value of mangrove forests, however, was ignored in this era, and the negative consequence was the massive retreat of mangrove trees observed over the last two decades (Figure 2).

The dikes behind the mangrove forests can enclose water, creating ponds between the mangroves and the dikes [19]. In addition, the level of the silty-clay layer on the beachfront has decreased, which led to scouring of the soil underneath the mangroves [20]. This, in turn, caused depletion of the mangroves.

The first mangrove rehabilitation project, which was funded by Sime Darby Plantation Sdn Bhd, was carried out on the southern part of Carey Island for three years between 2008 and 2010. That part of Carey Island, which faces the Strait of Malacca, was chosen for rehabilitation because of serious erosion and sustained forest degradation. In 2008, the University of Malaya conducted a pilot research project involving an innovative shoreline protection scheme to rehabilitate depleted mangrove forests on Carey Island. In this project, a coastal defense structure was integrated with ecological engineering methods.

The university directed construction of a detached breakwater system composed of a submerged breakwater with three segments separated by $2.5 \mathrm{~m}$ to allow for water circulation. Hashim et al. [20] reported that the average crest height of the breakwater system is $1.8 \mathrm{~m}$ above MSL. Furthermore, the system occupies nearly $60 \mathrm{~m}$ of the shore at the site. The system is approximately perpendicular to the coastline. The authors also presented detailed information on the breakwater design and described its implementation. Figure 3 illustrates the geographic position of the deforested area and the existing mangrove forest before the breakwater system was constructed in 2008. The figure also depicts the breakwater system and the dike after construction was completed.

Once the breakwater structure was finished in early 2009, mangroves were replanted. Nursery-raised 20-cm-tall seedlings of Rhizophora apiculata and Avicennia marina were

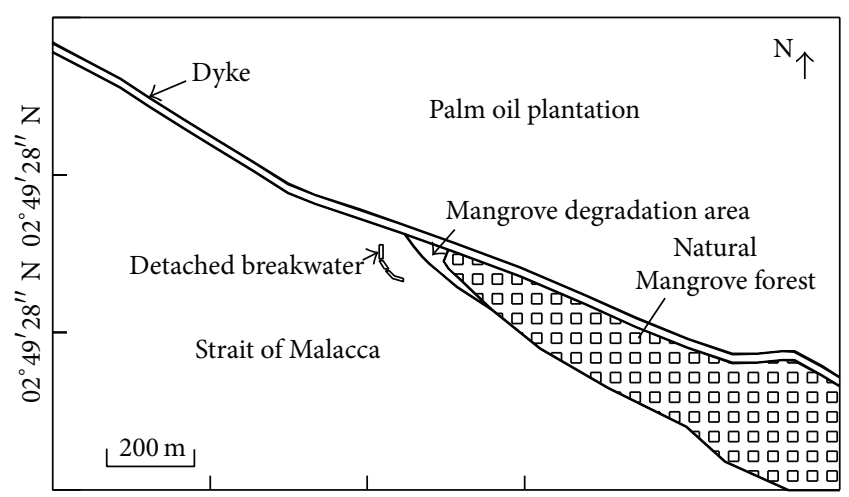

$101^{\circ} 20^{\prime} 22^{\prime \prime} \mathrm{E} 101^{\circ} 20^{\prime} 24^{\prime \prime} \mathrm{E} 101^{\circ} 20^{\prime} 26^{\prime \prime} \mathrm{E} 101^{\circ} 20^{\prime} 28^{\prime \prime} \mathrm{E}$

FIgURE 3: The schematic view of Carey Island after mangrove rehabilitation project in 2008 .

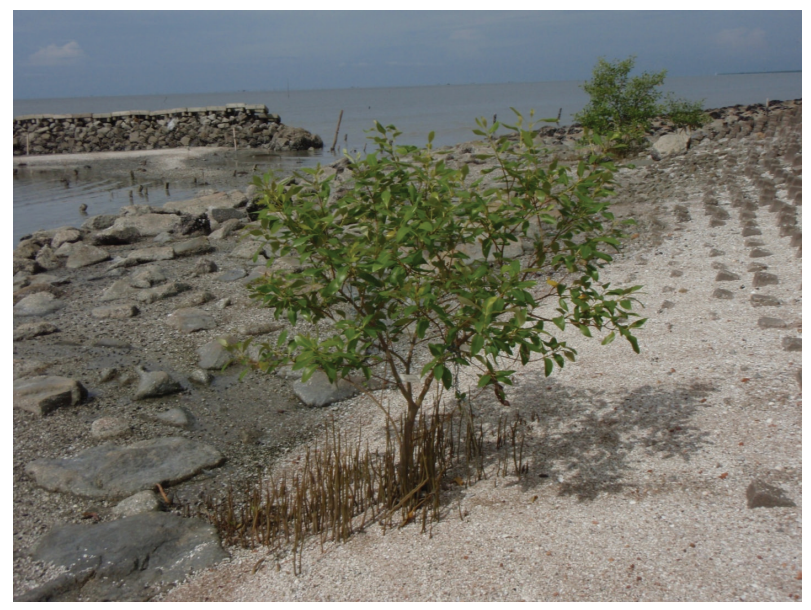

FIGURE 4: A row of natural recruits in the study site at the site near the detached breakwater (June 2014).

chosen because Avicennia marina is the most dominant species on Carey Island and Rhizophora apiculata is the major species at the target site [45]. Both species were planted in a grid system using coir logs and conventional planting methods. Almost all the planted seedlings died within one year because of toppling by high tides and waves (survivability index $=5 \%$ ).

Our most recent observation (June 2014) revealed a few new natural recruits outside the rehabilitation site. The natural recruits are Avicennia marina and Rhizophora apiculata, which are now more than $1 \mathrm{~m}$ tall with well-developed spreading root systems (Figure 4). The growth of natural recruits indicates that the site is now biologically ready for further mangrove rehabilitation. Based on our findings, trying to rehabilitate the mangrove forest at the target site is worthwhile.

\subsection{Characterization of the Carey Island Shoreline}

3.3.1. Sedimentologic Characterization. For this study, a stainless steel soil sampler was used to collect 36 soil samples from 
the Carey Island shoreline. The soil sampling was carried out in accordance with ASTM International's Standard Practice for Field Collection of Soil Samples for Subsequent Lead Determination (ASTM E 1727). We used sieving and hydrometer methods to obtain the particle size distribution of the soil samples. The tests were performed in accordance with the Standard Test Method for Particle-Size Analysis of Soils (ASTM D 422). According to the prerequisite criteria of ASTM D 422 , this test is applicable only to sediment including fine sand, silt, and clay particles that are larger than $0.075 \mathrm{~mm}$. Before carrying out the test, we removed carbonates, soluble salts, organic matter, and iron oxides from the samples. For all samples, the soil mass was dried and sieved.

3.3.2. Cross-Section Surface Profiling. The bathymetric data was collected using a TOPCON Total Station. The Temporary Bench Mark (TBM) was located at $2^{\circ} 49^{\prime} 28^{\prime \prime} \mathrm{N}, 101^{\circ} 20^{\prime} 25^{\prime \prime} \mathrm{E}$. Further, surface profiling was conducted in accordance with TBM along axis S5 in Figure 5 from 0 to $60 \mathrm{~m}$ of the existing dyke with the interval of $5 \mathrm{~m}$. Finally, the surveyed data points were corrected in relation to the coordinates taken from TBM [20].

We collected bathymetric data from Carey Island three times: in (1) December 2008 (before the detached breakwater system was constructed); (2) January 2010 (12 months after the detached breakwater system was complete); (3) January 2013 (48 months after the detached breakwater system was finished). The analysis of bathymetric data along the S5 axis in Figure 5 shows the variation of average elevation of a crosssection of the beach.

3.3.3. Hydrogeochemical Assessment. We performed an extensive study on the hydrogeochemical properties of soil and water samples taken from Carey Island's coastal zone. In all, we collected 36 water samples along axis S1 through axis S6 in Figure 5. Along each axis, six samples were taken at the longitudinal distance of $10 \mathrm{~m}$. The S1, S2, and S3 axes denote the area of existing mangroves (natural habitat) and the S4, S5, and S6 axes represent the restoration site. The natural habitat can be considered as the control site and the restoration site can be considered as the experimental site. The $\mathrm{pH}$ value, salinity index, nutrient concentration, and heavy metal content of the samples were measured.

We assessed the $\mathrm{pH}$ value for each of the 36 water samples using a multiprobe apparatus according to the Standard Test Methods for pH of Water (ASTM D 1293) [46].

Sample salinity was assessed using an Atago HandHeld Refractometer in accordance with Standard Methods for the Examination of Water and Wastewater (American Water Pollution Control Federation) [47]. Figure 5 shows the location of collected water samples for salinity test aligned along measurement axes S1 through S6.

The nutrient concentrations were measured via ICP (the 861-Advanced Compact; Australia/Switzerland) in accordance with ASTM Water Testing Standards in the "Inorganic Constituents in Water" series [48, 49]. In this study, we evaluated the concentration of nitrogen, sulfur, chlorine, calcium, manganese, and copper. The locations of collected water samples are depicted in Figure 5.

\section{Results and Discussion}

4.1. Sedimentology. Based on the soil analysis results, we found that sample consisted of $76.14 \%$ of silt and clay (on average) and only about $23.86 \%$ of fine sand. The mean grain size of the soil particle was $0.016 \mathrm{~mm}$. Most of studies done on Carey Island confirm these results, reporting that silt and clay were the dominant types of soil found on the island, ranging from $50 \%$ to $55 \%$ of total substrate soil composition $[33,45]$. Although mangroves can grow in sandy soils, they prefer to take root in fine clay and alluvial soil $[20,24]$. We observed a considerable increase in the amount of silt and clay constituents in this study.

An important part of a mangrove restoration project is finding a site with the most suitable conditions for mangrove establishment [31]. The existing remnants of mangroves in the Carey Island mud flat testify that the mud flat was once sedimentologically rich enough to retain mangrove roots. Therefore, restoring clay and silt to the site may result in more stable sedimentologic conditions that will help mangroves grow faster. We can conclude that the site is now sedimentologically ready for undertaking mangrove restoration projects.

4.2. Cross-Section Surface Profiling. Figure 6 shows the variation of elevation from July 2008 to January 2013. About four years into the project, the elevation of a cross-section along axis S5 in Figure 5 had increased considerably. For example, one month after construction, the elevation at the toe of the breakwater system rose from $0.2 \mathrm{~m}$ to $0.45 \mathrm{~m}$. After 12 months, it increased nearly $125 \%$. In the same way, the data collected in 2008 indicate that the elevation of the soil stratum at a distance of $30 \mathrm{~m}$ from the shoreline was about $0.5 \mathrm{~m}$, and as of January 2013, it had increased to $1.2 \mathrm{~m}$. The elevation was about $1.9 \mathrm{~m}$ near the coastal dike at a distance of $10 \mathrm{~m}$ from the shoreline in 2008. The elevation at the same location reached $2.2 \mathrm{~m}$ in January 2010. Finally, in January 2013, the elevation leveled at $2.4 \mathrm{~m}$. The sediment deposition trend is more noticeable near the breakwater than near the shoreline. Based on the positive trend of growth in the seabed level over time, we can conclude that the elevation of a cross section of the beach is increasing.

Detached breakwater systems are constructed not only to dampen the energy of waves to create a calm hydraulic environment in the nearshore zone but also to positively alter sediment deposition trends for compensation of transported littoral sediments [20]. Consequently, measuring sediment deposition elevation and collecting bathymetric data from near shore are essential to ensuring the success of any coastal protection project.

Generating a sedimentologic environment, that is, conducive to the establishment of mangroves, is crucial in ecological restoration projects [19]. The positive trend in sediment accumulation in the nearshore area indicates sedimentologic success after segmented breakwater systems have 


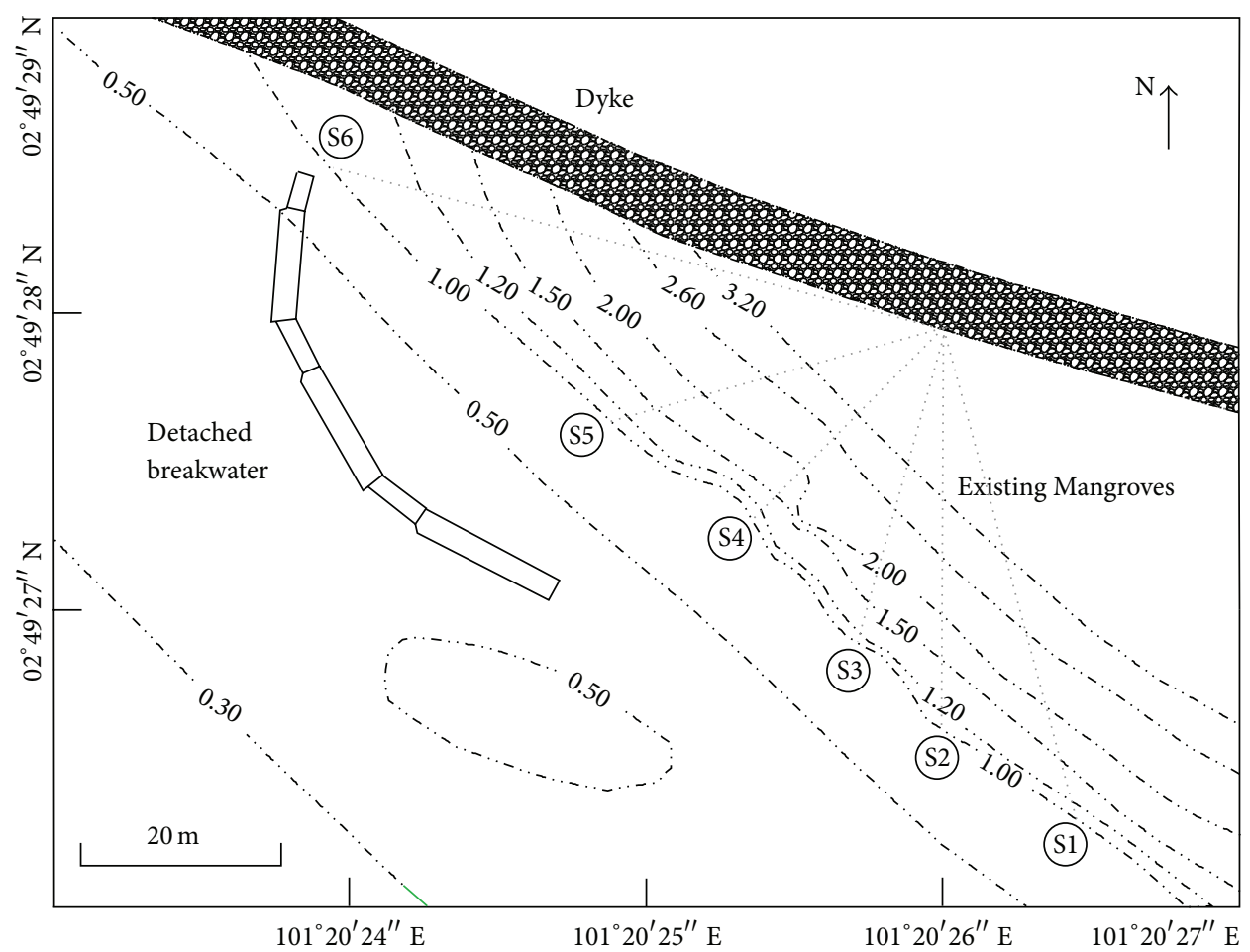

FIgURE 5: Thirty-six soil samples have been collected along S1 to S6 lines in various topographic elevations.

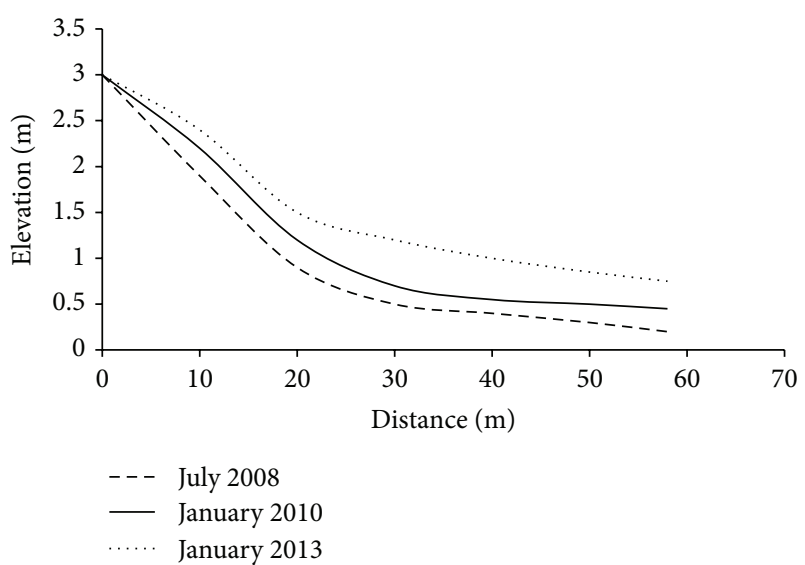

FIGURE 6: Observed elevation of sea bed level from December 2008 until January 2013 at the site.

been constructed [20]. We can conclude that the future establishment of mangroves would be successful at the target site based on the suitable seabed level.

\subsection{Hydrogeochemical Evaluation}

4.3.1. $\mathrm{pH}$ Value. The results show that the $\mathrm{pH}$ values in the soil water did not differ significantly between the reforestation site and the natural habitat. The average and standard deviation of $\mathrm{pH}$ value for the reforestation site is $7.23 \pm 0.19$; for the natural habitat, $\mathrm{pH}$ is $7.14 \pm 0.21$. This indicates that the $\mathrm{pH}$ values at both sites are slightly alkaline. Because mangroves can survive in neutral to high $\mathrm{pH}$ conditions [50], the $\mathrm{pH}$ level at this site is appropriate for planting mangroves.

The $\mathrm{pH}$ value is important in determining the chemical properties of water. Lower $\mathrm{pH}$ values $(<7)$ increase the metal availability in the medium because the hydrogen ion $\left(\mathrm{H}^{+}\right)$has a higher affinity for attracting negative charges and releasing the metals to the environment. Conversely, higher $\mathrm{pH}$ values $(>7)$ decrease the metal availability of the soil because the hydroxyl ion $\left(\mathrm{OH}^{-}\right)$has high potential to attract positive charges and lower the availability of metals in the soil and water [51]. The $\mathrm{pH}$ values measured, then, show that the water samples are slightly alkaline. The slight alkalinity of samples can reduce the concentration of heavy metal ions along the observed coastal zone.

4.3.2. Salinity Index. The mean value of salinity for the reforestation site ranged between $24.3 \pm 0.43 \mathrm{ppt}$ and $29.2 \pm$ $0.12 \mathrm{ppt}$ (average $=26.9 \pm 0.15$ ). For the natural habitat, the values ranged from $25.7 \pm 0.57 \mathrm{ppt}$ to $28.3 \pm 0.74 \mathrm{ppt}$ (average $=26.3 \pm 0.62 \mathrm{ppt}$ ). Therefore, the results show that the salinity in the water samples did not vary significantly between the reforestation site and the natural habitat.

Salinity plays an important role in determination of water and soil properties. Salinity is dominantly affected by bathymetric properties [52]. At lower sea levels, the salinity is naturally maintained between 33 ppt (part per thousand) and $38 \mathrm{ppt}$; in highly elevated zones, the salinity might vary between $1 \mathrm{ppt}$ and $25 \mathrm{ppt}$ [53]. In addition, Joshi and Ghose [54] stated that the salinity of a medium decreases as 
the distance from the coastline increases. Therefore, the lower the elevation of a seabed, the higher the salinity.

Mangroves are well known for their halophyte characteristics [55], which allow them to survive in high salinity through certain mechanisms of salt tolerance [50]. This explains the dense mangrove community in the seaward fringe and riverine estuaries where the salinity is high. For example, the seaward mangrove species (i.e., Avicennia marina) has evolved over the years to be more flexible in high salinity and $\mathrm{pH}$ environments [52].

Salinity greatly affects the growth of plants. Various studies have been conducted to examine the survival of mangroves in different salinity ranges [56-59]. Avicennia marina is always recognized as the one of the most salttolerant mangrove species because it naturally grows on the waterfront $[56,58]$. Conversely, many other mangrove species cannot survive on the seafront because they cannot tolerate higher water salinity $[52,59]$. Clearly, selecting the proper mangrove species for the local conditions is crucial for successful restoration projects.

The same mangrove species could have different tolerances to salinity depending on the region. Aziz and Khan [52] discovered that, in India, Avicennia marina can survive in semiarid to saline deserts and is highly salt-tolerant up to 35 ppt. However, it has been found that Avicennia marina in Hong Kong can barely survive in salinity higher than $15 \mathrm{ppt}$ [60]. In Malaysian coastal zones, mangroves can survive in salinity between $20 \mathrm{ppt}$ and $30 \mathrm{ppt}$ [33]. We found that the salinity ranges from $24.3 \pm 0.43$ to $29.2 \pm 0.12 \mathrm{ppt}$ (average $=26.9 \pm 0.15 \mathrm{ppt}$ ) on Carey Island. We can conclude, then, that the target site is suitable for natural recruits of Avicennia marina.

4.3.3. Nutrient Concentrations. During palm cultivation on Carey Island, the use of fertilizer is inevitable. The target site of this study is near three rivers: Air Hitam, Judah, and Keluang [40]. The associated surface water runoff can bring fertilizer remnants into the rehabilitation site because the site is at the edge of the palm plantation areas. In addition, the growth of mangroves is more noticeable near riverine locations and fringe areas where the nutrients can be transported [61]. Because mangrove seedlings could use the abundant nutrients in the sediment to establish themselves, quantifying the nutrient content at the site is worthwhile.

Nutrients are essential chemical components required for plant growth and life-cycle completion. Nutrient-rich sediments quicken the growth of mangrove seedlings [61]. In this section, we quantitatively assess nonorganic nutrients in the soil and water samples. Nonorganic nutrients can be separated into two major groups: macronutrients and micronutrients. Plants usually require large proportions of macronutrients to grow (occurrence of internal chemomalicious activities) [62]. On the other hand, micronutrients are required in smaller amounts to be involved in catalytic and regulatory mechanisms [60]. If the micronutrients exceed an acceptable level, they can toxify plants [51]. In such conditions, the micronutrients are also called "heavy metals" [51]. Table 1 presents nutrient concentrations, which are discussed in detail in the sections that follow.
Nitrogen is a vital element for the growth of plants. Nitrogen in soil can be found in either organic or inorganic form. The organic nitrogen in soil is composed of small plant residues, small living organisms, and decomposing organic matter. The inorganic form is nitrate $\left(\mathrm{NO}_{3}{ }^{-}\right)$or ammonium $\left(\mathrm{NO}_{4}{ }^{+}\right)$[63]. According to Table 1 , the nitrate concentrations at the reforestation site were recorded in the range from $22.69 \pm 0.19 \mathrm{ppm}$ to $57.39 \pm 0.33 \mathrm{ppm}$ (average $=42.1 \pm$ $0.27 \mathrm{ppm}$ ). The allowable range of nitrogen in the soil is between $10 \mathrm{ppm}$ to $60 \mathrm{ppm}$ [55], so nitrogen is in the normal range at the reforestation site. Conversely, no nitrate was found at the natural habitat. This might be related to the consumption of nitrogen through processes such as bacterial nitrification, ammonia valorization, and denitrification [63]. We can conclude that the reforestation site has enough nitrogen for mangrove establishment.

Sulfur is the essential chemical component of the structure of plants and biological processes. Plants use sulfur in the form of sulfate $\left(\mathrm{SO}_{4}{ }^{2-}\right)$ [62]. The observed value of sulfate is almost the same at the reforestation site $(1.56 \pm 0.38 \mathrm{ppm}$ to $4.01 \pm 0.12 \mathrm{ppm}$, average $=2.71 \pm 0.51 \mathrm{ppm})$ and the natural habitat $(1.78 \pm 0.58 \mathrm{ppm}$ to $4.39 \pm 0.86 \mathrm{ppm}$, average $=2.73 \pm$ $0.62 \mathrm{ppm})$. The minimum value for sulfate in the coastal area must not be less than $2 \mathrm{ppm}$ [64]. There is sufficient sulfate at both sites, and the reforestation site has enough sulfate for mangrove establishment.

Chlorine is an important chemical element for photosynthetic reactions in plants [62]. Plants use chlorine in the form of chloride $\left(\mathrm{Cl}^{-}\right)$, a highly abundant and soluble element in the environment. The chloride concentration at the reforestation site was higher $(15.46 \pm 0.41-32.84 \pm$ $0.76 \mathrm{ppm}$, average $=26.76 \pm 0.84 \mathrm{ppm}$ ) than that at the natural habitat $12.08 \pm 0.37-27.91 \pm 0.54 \mathrm{ppm}$, average $=19.32 \pm$ $0.41 \mathrm{ppm})$. Generally, the mangroves can endure chloride salts up to $106 \mathrm{ppm}$ [63], so the amount of detected chloride in the study area cannot be regarded as the cause of mangrove degradation. The chloride content at the reforestation site is within the allowable range.

Calcium and magnesium are important nutrients for plant growth $[63,65]$. The concentrations of calcium $(260.28$ $\pm 0.79-314.81 \pm 0.11 \mathrm{ppm}$, average $=281.16 \pm 0.36 \mathrm{ppm})$ and magnesium $(265.47 \pm 0.94-325.71 \pm 0.21 \mathrm{ppm}$, average $=$ $291.23 \pm 0.36 \mathrm{ppm}$ ) at the reforestation site were reasonably similar to the natural habitat concentrations of calcium $(151.60 \pm 0.16 \mathrm{ppm}-311.47 \pm 0.52 \mathrm{ppm}$, average $=273.19$ $\pm 0.48 \mathrm{ppm})$ and magnesium $(209.00 \pm 0.49 \mathrm{ppm}-255.77$ $\pm 0.87 \mathrm{ppm}$, average $=283.34 \pm 0.36 \mathrm{ppm})$. Clemens [66] claimed that calcium and magnesium should be classified as noncritical metals if the calcium amount is below $500 \mathrm{ppm}$ and the magnesium content is below $300 \mathrm{ppm}$. The obtained concentrations of both nutrients can be considered normal, meaning that the reforestation site is an appropriate ground for mangrove establishment.

Manganese acts as an activator of several enzymes in plants responsible for the photosynthesis, respiration, and synthesis of proteins $[64,67,68]$. The manganese content should be in the range between $0.01 \mathrm{ppm}$ and $0.8 \mathrm{ppm}$ [69]. The manganese concentration at the reforestation site 
TABLE 1: The range of nutrient concentration at reforestation site.

\begin{tabular}{|c|c|c|c|}
\hline Nutrient concentration (ppm) & Reforestation site (ppm) & Natural habitat (ppm) & Concentration considered toxic (ppm) \\
\hline \multicolumn{4}{|l|}{ Macronutrient } \\
\hline Nitrogen $(\mathrm{N})$ & $22.69-57.39$ & 0 & $10-60^{\mathrm{a}}$ \\
\hline Calcium (Ca) & $260.28-314.81$ & $151.60-311.47$ & $<500^{\mathrm{b}}$ \\
\hline Magnesium (Mg) & $265.47-325.71$ & $209.00-255.77$ & $<300^{\mathrm{b}}$ \\
\hline Sulphur (S) & $1.56-4.01$ & $1.78-4.39$ & $>2^{\mathrm{c}}$ \\
\hline \multicolumn{4}{|l|}{ Micronutrients } \\
\hline Manganese (Mn) & $0.09-0.78$ & $0.01-0.38$ & $0.01-0.8^{\mathrm{c}}$ \\
\hline Chlorine $(\mathrm{Cl})$ & $15.46-32.84$ & $12.08-27.91$ & $120-300^{\mathrm{d}}$ \\
\hline Copper $(\mathrm{Cu})$ & $0.01-0.02$ & $0.02-0.04$ & $0.02-0.05^{\mathrm{d}}$ \\
\hline
\end{tabular}

Note: ${ }^{\mathrm{a}}$ Gong and Ong [55], ${ }^{\mathrm{b}}$ Clemens [66], ${ }^{\mathrm{c}}$ Reddy and DeLaune [69] and ${ }^{\mathrm{d}}$ Hopkins and Hüner [62].

$(0.09 \pm 0.29-0.78 \pm 0.74 \mathrm{ppm}$, average $=0.36 \pm 0.31 \mathrm{ppm})$ is a little higher than that of the natural habitat $(0.01 \pm$ $0.06-0.38 \pm 0.24 \mathrm{ppm}$, average $=0.29 \pm 0.44 \mathrm{ppm})$. The concentrations of manganese at both sites are considered favorable for mangrove growth.

Copper is classified as a metal that is extremely toxic to plants (Reddy and D'Angelo 1997) [64]. The presence of excessive copper content in the soil and water near plants leads to chlorosis, yellow coloration, and retardation of plant growth [62]. The concentration of copper is slightly higher at the natural habitat $(0.02 \pm 0.53-0.04 \pm 0.17 \mathrm{ppm}$, average $=0.037 \pm 0.31 \mathrm{ppm})$ than at the reforestation area $(0.01 \pm$ $0.63-0.02 \pm 0.27 \mathrm{ppm}$, average $=0.031 \pm 0.68 \mathrm{ppm})$. The average allowable value of copper in plants and soil is between $0.02 \mathrm{ppm}$ and $0.05 \mathrm{ppm}$ [69]. The current concentration of copper at both sites is considered normal for plant growth.

In summary, we can conclude that the reforestation site is suitable for further attempts to rehabilitate the lost mangroves because the concentrations of nutrients are favorable for their growth. Future mangrove rehabilitation trials can be successful with a slight alteration in wave energy reduction, entrapment of sediments to elevate the geotechnical datum, and rigorous anthropogenic control.

4.4. Cost Estimation for the Mangrove Rehabilitation Project. It is difficult to estimate costs for the mangrove rehabilitation projects in detail. Because the allocated budgets for the projects are relatively higher than the actual costs, a detailed cost estimation would help reduce unnecessary budgeting and might prevent inaccurate financial estimations [70, 71]. Based on the available project documents, we present a detailed cost estimation of the mangrove rehabilitation project integrated with the coastal protection system in this section.

According to the Department of Statistics Malaysia, the average inflation rate was about $2.66 \%$ between 2005 and 2013. Table 2 presents the cost estimation for the full length of a structural part of the project including an 80-m-long and 2.5-m-wide detached breakwater system. The construction of the detached breakwater system for $1,920 \mathrm{~m}^{2}$ (the total occupied area of detached breakwater system) costs USD 23,154 . Considering the inflation rate of $2.66 \%$ over the four years following construction, construction costs reached
USD 25,910 in 2013. The financial estimates in mangrove restoration projects are reported for $0.01 \mathrm{~km}^{2}$ rather than for the area of the study site. As a result, the total construction cost for the detached breakwater system was USD 121,000 per $0.01 \mathrm{~km}^{2}$, which reached USD 135 thousand per $0.01 \mathrm{~km}^{2}$ considering the inflation rate over five years.

Table 3 presents the detailed cost estimation for the mangrove replantation. Between April 2009 and April 2010, 679 Avicennia marina and 351 Rhizophora apiculata mangroves were planted at the rehabilitation site. The total cost of mangrove replantation for $1,920 \mathrm{~m}^{2}$ was USD 3,366. After considering the inflation rate, it would be USD 3,814 in present time. At the time of the project, mangrove replantation at the site cost USD 175,000 per $0.01 \mathrm{~km}^{2}$. After taking the inflation rate into account, it would be USD 199,000 per $0.01 \mathrm{~km}^{2}$ in present time. These numbers imply that at a large scale, mangrove replantation is more costly than construction of coastal protection structures.

In conclusion, the total budget of the project, including the detached breakwater construction and the mangrove replantation, was about USD 296,000 per $0.01 \mathrm{~km}^{2}$ in 2008 . Considering the inflation rate, it would cost USD 336,000 per $0.01 \mathrm{~km}^{2}$ in 2013 . The aim of this part of our study was to introduce the detailed cost estimation of the project based on the available documents. The process of cost estimation can serve as a good reference for future projects.

\section{Conclusion}

In this paper, we provided a history of coastal protection practices in Malaysia since 1950. We also presented an example of an innovative mangrove restoration project on Carey Island, and investigated the feasibility of success for future mangrove rehabilitation projects at the site. Four years after the construction of the breakwater system, the sedimentologic characterization and bathymetric properties of the site have been enhanced. We found that silt and clay content had increased at the site up to $76.14 \%$ (on average) of collected samples and only about $23.86 \%$ of fine sand. The bathymetric data show an increase in seabed elevation after four years into the project. Based on the positive trend of growth in the seabed level over time, we can conclude that 


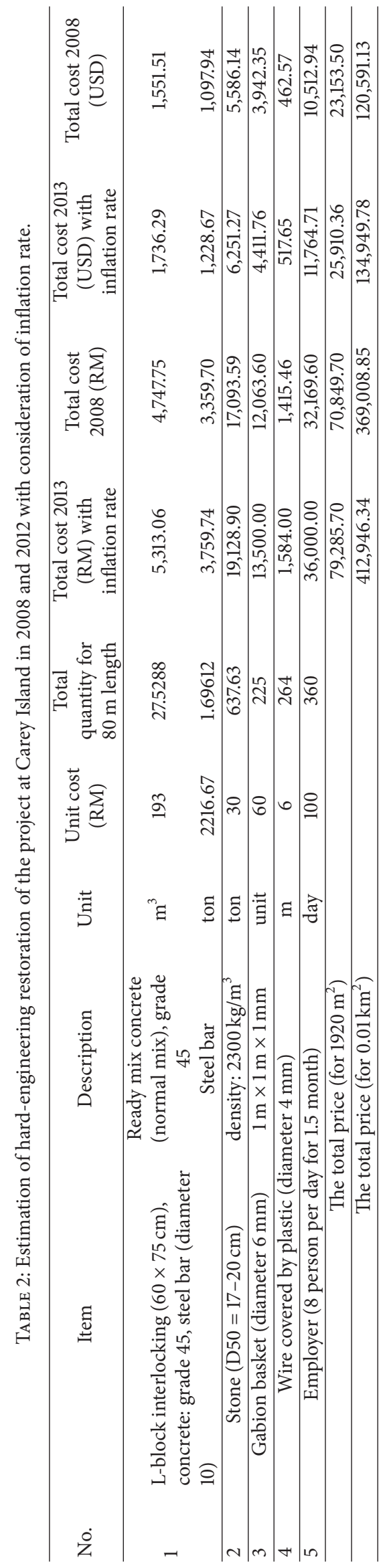


TABLE 3: Estimation of replanted mangrove saplings of the project at Carey Island in 2008 and 2012 with consideration of inflation rate.

\begin{tabular}{|c|c|c|c|c|c|c|c|}
\hline No. & $\begin{array}{l}\text { Species of the } \\
\text { mangrove }\end{array}$ & $\begin{array}{l}\text { Price per unit (including } \\
\text { the planting and } \\
\text { transportation prices) }\end{array}$ & $\begin{array}{c}\text { Number of } \\
\text { mangrove }\end{array}$ & $\begin{array}{l}\text { Total cost } 2008 \\
\quad(\mathrm{RM})\end{array}$ & $\begin{array}{l}\text { Total cost } 2013 \\
(\mathrm{RM}) \text { with } \\
\text { inflation rate }\end{array}$ & $\begin{array}{c}\text { Total cost } \\
2008 \text { (USD) }\end{array}$ & $\begin{array}{l}\text { Total cost } 2013 \\
\text { (USD) with } \\
\text { inflation rate }\end{array}$ \\
\hline 1 & $\begin{array}{c}\text { Avicennia } \\
\text { marina }\end{array}$ & 10 & 679 & $6,790.00$ & $7,693.07$ & 2,218.95 & $2,514.08$ \\
\hline 2 & $\begin{array}{l}\text { Rhizophora } \\
\text { apiculata }\end{array}$ & 10 & 351 & $3,510.00$ & $3,976.83$ & $1,147.06$ & $1,299.62$ \\
\hline \multicolumn{4}{|c|}{ Total price $\left(\right.$ for $1920 \mathrm{~m}^{2}$ ) } & $10,300.00$ & $11,669.9$ & $3,366.01$ & $3,813.69$ \\
\hline \multicolumn{4}{|c|}{ Total price (for $0.01 \mathrm{~km}^{2}$ ) } & $536,458.33$ & $607,807.29$ & $175,313.18$ & $198,629.83$ \\
\hline
\end{tabular}

the elevation of a cross section of the beach is increasing. The $\mathrm{pH}$ value, salinity index, nutrient concentration, and heavy metal content of the samples were measured. In addition, according to the hydrogeochemical assessment, the site is conducive to establishing mangroves. Based on our findings, trying to rehabilitate the mangrove forest at the target site is worthwhile. For successful restoration, however, future research must focus on selecting mangrove species that can live in harmony with existing vegetation.

\section{Conflict of Interests}

The authors declare that there is no conflict of interests regarding the publication of this paper.

\section{Acknowledgments}

The authors are very grateful for the valuable comments and suggestions of the reviewers. The authors express their sincere thanks for the funding support they received from HIR-MOHE University of Malaya under Grant no. UM.C/HIR/MOHE/ENG/34.

\section{References}

[1] L. Dominguez, "Beyond biology: can we reconcile the landwater-humankind interface?” Fisheries, vol. 38, no. 2, pp. 84-86, 2013.

[2] H. Behling and M. L. da Costa, "Holocene environmental changes from the Rio Curua record in the Caxiuana region, Eastern Amazon Basin," Quaternary Research, vol. 53, no. 3, pp. 369-377, 2000.

[3] M. Elliott, D. Burdon, K. L. Hemingway, and S. E. Apitz, "Estuarine, coastal and marine ecosystem restoration: confusing management and science-a revision of concepts," Estuarine, Coastal and Shelf Science, vol. 74, no. 3, pp. 349-366, 2007.

[4] D. Brunsden, "A critical assessment of the sensitivity concept in geomorphology," CATENA, vol. 42, no. 2-4, pp. 99-123, 2001.

[5] J. D. Hansom, "Coastal sensitivity to environmental change: a view from the beach," Catena, vol. 42, no. 2-4, pp. 291-305, 2001.

[6] J. Pethick, "Coastal management and sea-level rise," Catena, vol. 42, no. 2-4, pp. 307-322, 2001.

[7] J. Bell and C. E. Lovelock, "Insuring mangrove forests for their role in mitigating coastal erosion and storm-surge: an australian case study," Wetlands, vol. 33, no. 2, pp. 279-289, 2013.
[8] M. M. El Banna and O. E. Frihy, "Human-induced changes in the geomorphology of the northeastern coast of the Nile delta, Egypt," Geomorphology, vol. 107, no. 1-2, pp. 72-78, 2009.

[9] M. L. Kirwan and J. P. Megonigal, "Tidal wetland stability in the face of human impacts and sea-level rise," Nature, vol. 504, pp. 53-60, 2013.

[10] M. Capobianco and M. J. F. Stive, "Soft intervention technology as a tool for integrated coastal zone management," Journal of Coastal Conservation, vol. 6, no. 1, pp. 33-40, 2000.

[11] M. E. Hanley, S. P. G. Hoggart, D. J. Simmonds et al., "Shifting sands? Coastal protection by sand banks, beaches and dunes," Coastal Engineering, vol. 87, pp. 136-146, 2014.

[12] S. D. Bergen, S. M. Bolton, and J. L. Fridley, "Design principles for ecological engineering," Ecological Engineering, vol. 18, no. 2, pp. 201-210, 2001.

[13] H. T. Odum and B. Odum, "Concepts and methods of ecological engineering," Ecological Engineering, vol. 20, no. 5, pp. 339-361, 2003.

[14] L. B. Firth, R. C. Thompson, K. Bohn, M. Abbiati, L. Airoldi, and T. J. Bouma, "Between a rock and a hard place: environmental and engineering considerations when designing coastal defence structures," Coastal Engineering, vol. 87, pp. 122-135, 2014.

[15] A. Behnia, H. K. Chai, N. Ranjbar, and N. Behnia, "Finite element analysis of the dynamic response of composite floors subjected to walking induced vibrations," Advances in Structural Engineering, vol. 16, no. 5, pp. 959-974, 2013.

[16] W. J. Mitsch, "What is ecological engineering?" Ecological Engineering, vol. 45, pp. 5-12, 2012.

[17] I. Valiela, J. L. Bowen, and J. K. York, "Mangrove forests: One of the world's threatened major tropical environments," BioScience, vol. 51, no. 10, pp. 807-815, 2001.

[18] P. J. Mumby, "Connectivity of reef fish between mangroves and coral reefs: algorithms for the design of marine reserves at seascape scales," Biological Conservation, vol. 128, no. 2, pp. 215222, 2006.

[19] B. Kamali and R. Hashim, "Mangrove restoration without planting," Ecological Engineering, vol. 37, no. 2, pp. 387-391, 2011.

[20] R. Hashim, B. Kamali, N. M. Tamin, and R. Zakaria, "An integrated approach to coastal rehabilitation: mangrove restoration in Sungai Haji Dorani, Malaysia," Estuarine, Coastal and Shelf Science, vol. 86, no. 1, pp. 118-124, 2010.

[21] D. M. Alongi, "Mangrove forests of timor-leste: ecology, degradation and vulnerability to climate change," in Mangrove Ecosystems of Asia: Status, Challenges and Management Strategies, I. Faridah-Hanum, A. Latiff, K. R. Hakeem, and M. Ozturk, Eds., SE-9, pp. 199-212, Springer, New York, NY, USA, 2014. 
[22] N. H. M. Ghazali, "Coastal erosion and reclamation in Malaysia," Aquatic Ecosystem Health and Management, vol. 9, no. 2, pp. 237-247, 2006.

[23] C. Giri, E. Ochieng, L. L. Tieszen et al., "Status and distribution of mangrove forests of the world using earth observation satellite data," Global Ecology and Biogeography, vol. 20, no. 1, pp. 154-159, 2011.

[24] F. Blasco, P. Saenger, and E. Janodet, "Mangroves as indicators of coastal change," Catena, vol. 27, no. 3-4, pp. 167-178, 1996.

[25] R. R. Lewis III, "Ecological engineering for successful management and restoration of mangrove forests," Ecological Engineering, vol. 24, no. 4, pp. 403-418, 2005.

[26] N. M. Tamin, R. Zakaria, R. Hashim, and Y. Yin, "Establishment of Avicennia marina mangroves on accreting coastline at Sungai Haji Dorani, Selangor, Malaysia," Estuarine, Coastal and Shelf Science, vol. 94, no. 4, pp. 334-342, 2011.

[27] H. J. Teas, "Ecology and restoration of mangrove shorelines in Florida," Environmental Conservation, vol. 4, no. 1, pp. 51-58, 1977.

[28] D. A. Luther and R. Greenberg, "Mangroves: a global perspective on the evolution and conservation of their terrestrial vertebrates," BioScience, vol. 59, no. 7, pp. 602-612, 2009.

[29] M. A. Othman, "Value of mangroves in coastal protection," Hydrobiologia, vol. 285, no. 1-3, pp. 277-282, 1994.

[30] C. M. Duarte, I. J. Losada, I. E. Hendriks, I. Mazarrasa, and N. Marba, "The role of coastal plant communities for climate change mitigation and adaptation," Nature Climate Change, vol. 3, pp. 961-968, 2013.

[31] D. M. Alongi, "Present state and future of the world's mangrove forests," Environmental Conservation, vol. 29, no. 3, pp. 331-349, 2002.

[32] E. L. Gilman, J. Ellison, N. C. Duke, and C. Field, "Threats to mangroves from climate change and adaptation options: a review," Aquatic Botany, vol. 89, no. 2, pp. 237-250, 2008.

[33] N. A. M. Affandi, B. Kamali, R. Mz, N. M. Tamin, and R. Hashim, "Early growth and survival of Avicennia alba seedlings under excessive sedimentation," Scientific Research and Essays, vol. 5, no. 18, pp. 2801-2805, 2010.

[34] A. M. Kerr, A. H. Baird, and S. J. Campbell, "Comments on "Coastal mangrove forests mitigated tsunami" by K. Kathiresan and N. Rajendran [Estuar. Coast. Shelf Sci. 65 (2005) 601-606]," Estuarine, Coastal and Shelf Science, vol. 67, no. 3, pp. 539-541, 2006.

[35] J. Yang, J. Gao, B. Liu, and W. Zhang, "Sediment deposits and organic carbon sequestration along mangrove coasts of the Leizhou Peninsula, southern China," Estuarine, Coastal and Shelf Science, vol. 136, pp. 3-10, 2014.

[36] M. P. Kumara, L. P. Jayatissa, K. W. Krauss, D. H. Phillips, and M. Huxham, "High mangrove density enhances surface accretion, surface elevation change, and tree survival in coastal areas susceptible to sea-level rise," Oecologia, vol. 164, no. 2, pp. 545-553, 2010.

[37] D. Di Nitto, G. Neukermans, N. Koedam et al., "Mangroves facing climate change: landward migration potential in response to projected scenarios of sea level rise," Biogeosciences Discussions, vol. 10, no. 2, pp. 3523-3558, 2014.

[38] M. F. Tajul Baharuddin, S. Taib, R. Hashim, M. H. Z. Abidin, and N. I. Rahman, "Assessment of seawater intrusion to the agricultural sustainability at the coastal area of Carey Island, Selangor, Malaysia," Arabian Journal of Geosciences, vol. 6, no. 10, pp. 3909-3928, 2013.
[39] M. Baba, "Geology quaternary at Teluk Datuk area, State of Selangor (sheet 101)," Geology Quaternary Report, Department of Minerals and Geoscience, Sabah, Malaysia, 1997 (Malaysian).

[40] T. Suntharalingam and L. Teoh, "Quaternary geology of the coastal plains of Taiping," Quaternary Geology Report, 1985.

[41] M. F. Tajul Baharuddin, A. R. Othman, S. Taib, R. Hashim, M. H. Zainal Abidin, and M. A. Radzuan, "Evaluating freshwater lens morphology affected by seawater intrusion using chemistryresistivity integrated technique: a case study of two different land covers in Carey Island, Malaysia," Environmental Earth Sciences, vol. 69, pp. 2779-2797, 2013.

[42] E. Meilianda, C. M. Dohmen-Janssen, B. H. P. Maathuis, S. J. M. H. Hulscher, and J. P. M. Mulder, "Short-term morphological responses and developments of Banda Aceh coast, Sumatra Island, Indonesia after the tsunami on 26 December 2004," Marine Geology, vol. 275, no. 1-4, pp. 96-109, 2010.

[43] M. N. M. Nawawi, Z. Z. T. Harith, M. S. Ayub, A. N. Ibrahim, and A. Alphonse, "Modeling of an undergroundwater aquifer using 2-D electrical imaging technique in Brooklands Plantation," in Proceedings of the 2nd International Symposium on Geophysics, pp. 293-297, Tanta, Egypt, 2001.

[44] A. M. Muzathik, W. B. Wan Nik, K. B. Samo, and M. Z. Ibrahim, "Ocean wave measurement and wave climate prediction of Peninsular Malaysia," Journal of Physical Science, vol. 22, no. 1, pp. 77-92, 2011.

[45] R. Saraswathy, M. Z. Rozainah, and G. Redzwan, "Diversity and biomass estimation of mangrove trees on carey Island, Malaysia," Ecology, Environment and Conservation, vol. 15, no. 2, pp. 205-211, 2009.

[46] E. Castañeda-Moya, R. R. Twilley, V. H. Rivera-Monroy, B. D. Marx, C. Coronado-Molina, and S. M. L. Ewe, "Patterns of root dynamics in mangrove forests along environmental gradients in the Florida Coastal Everglades, USA," Ecosystems, vol. 14, no. 7, pp. 1178-1195, 2011.

[47] R. S. Comeaux, M. A. Allison, and T. S. Bianchi, "Mangrove expansion in the Gulf of Mexico with climate change: implications for wetland health and resistance to rising sea levels," Estuarine, Coastal and Shelf Science, vol. 96, no. 1, pp. 81-95, 2012.

[48] B. Fry and N. Cormier, "Chemical ecology of red mangroves, rhizophora mangle, in the Hawaiian Islands," Pacific Science, vol. 65 , no. 2, pp. 219-234, 2011.

[49] C. C. Da Cruz, U. N. Mendoza, J. B. Queiroz, J. F. Berrêdo, S. V. Da Costa Neto, and R. J. Lara, "Distribution of mangrove vegetation along inundation, phosphorus, and salinity gradients on the Bragança Peninsula in Northern Brazil," Plant and Soil, vol. 370, no. 1-2, pp. 393-406, 2013.

[50] S. Wakushima, S. Kuraishi, and N. Sakurai, "Soil salinity and $\mathrm{pH}$ in Japanese mangrove forests and growth of cultivated mangrove plants in different soil conditions," Journal of Plant Research, vol. 107, no. 1, pp. 39-46, 1994.

[51] Y. D. Jing, Z. L. He, and X. E. Yang, "Effects of pH, organic acids, and competitive cations on mercury desorption in soils," Chemosphere, vol. 69, no. 10, pp. 1662-1669, 2007.

[52] I. Aziz and M. A. Khan, "Experimental assessment of salinity tolerance of Ceriops tagal seedlings and saplings from the Indus delta, Pakistan," Aquatic Botany, vol. 70, no. 3, pp. 259-268, 2001.

[53] I. A. Mendelssohn and N. L. Kuhn, "Sediment subsidy: effects on soil-plant responses in a rapidly submerging coastal salt marsh," Ecological Engineering, vol. 21, no. 2-3, pp. 115-128, 2003. 
[54] H. Joshi and M. Ghose, "Forest structure and species distribution along soil salinity and $\mathrm{pH}$ gradient in mangrove swamps of the Sundarbans," Tropical Ecology, vol. 44, no. 2, pp. 197-206, 2003.

[55] W. Gong and J. Ong, "Plant biomass and nutrient flux in a managed mangrove forest in Malaysia," Estuarine, Coastal and Shelf Science, vol. 31, no. 5, pp. 519-530, 1990.

[56] M. Basyuni, S. Baba, Y. Kinjo, and H. Oku, "Salinity increases the triterpenoid content of a salt secretor and a non-salt secretor mangrove," Aquatic Botany, vol. 97, no. 1, pp. 17-23, 2012.

[57] H. A. Monsef, A. S. H. Aguib, and S. E. Smith, "Locating suitable mangrove plantation sites along the Saudi Arabia Red Sea Coast," Journal of African Earth Sciences, vol. 83, pp. 1-9, 2013.

[58] A. Sreeshan, S. P. Meera, and A. Augustine, "A review on transporters in salt tolerant mangroves," Trees, pp. 1-14, 2014.

[59] A. Das and R. Strasser, "Salinity-induced genes and molecular basis of salt-tolerant strategies in Mangroves," in Molecular Stress Physiology of Plants, G. R. Rout and A. B. Das, Eds., SE-3, pp. 53-86, Springer, New Delhi, India, 2013.

[60] Y. Ye, N. F.-Y. Tam, C.-Y. Lu, and Y.-S. Wong, "Effects of salinity on germination, seedling growth and physiology of three saltsecreting mangrove species," Aquatic Botany, vol. 83, no. 3, pp. 193-205, 2005.

[61] C. M. Duarte, O. Geertz-Hansen, U. Thampanya et al., "Relationship between sediment conditions and mangrove Rhizophora apiculata seedling growth and nutrient status," Marine Ecology Progress Series, vol. 175, pp. 277-283, 1998.

[62] W. Hopkins and N. Hüner, Introduction to Plant Physiology, vol. 355, John Wiley \& Sons, New York, NY, USA, 3rd edition, 2004.

[63] J. Meyer, B. C. Kelley, and P. M. Vignais, "Nitrogen fixation and hydrogen metabolism in photosynthetic bacteria," Biochimie, vol. 60 , no. 3, pp. 245-260, 1978.

[64] K. R. Reddy and E. M. D’Angelo, "Biogeochemical indicators to evaluate pollutant removal efficiency in constructed wetlands," Water Science and Technology, vol. 35, no. 5, pp. 1-10, 1997.

[65] C. Axelsson, A. K. Skidmore, M. Schlerf, A. Fauzi, and W. Verhoef, "Hyperspectral analysis of mangrove foliar chemistry using PLSR and support vector regression," International Journal of Remote Sensing, vol. 34, no. 5, pp. 1724-1743, 2013.

[66] S. Clemens, "Toxic metal accumulation, responses to exposure and mechanisms of tolerance in plants," Biochimie, vol. 88, pp. 1707-1719, 2006.

[67] A. Kashem and B. R. Singh, "Heavy metal contamination of soil and vegetation in the vicinity of industries in Bangladesh," Water, Air, and Soil Pollution, vol. 115, no. 1-4, pp. 347-361, 1999.

[68] X. L. Otero, T. O. Ferreira, M. A. Huerta-Díaz et al., “Geochemistry of iron and manganese in soils and sediments of a mangrove system, Island of Pai Matos (Cananeia-SP, Brazil)," Geoderma, vol. 148, no. 3-4, pp. 318-335, 2009.

[69] K. R. Reddy and R. D. DeLaune, Biogeochemistry of Wetlands: Science and Applications, CRC Press, 2004.

[70] S. Shamshirband, D. Petković, Ž. Ćojbašić et al., "Adaptive neuro-fuzzy optimization of wind farm project net profit," Energy Conversion and Management, vol. 80, pp. 229-237, 2014.

[71] S. Motamedi, K.-I. Song, and R. Hashim, "Prediction of unconfined compressive strength of pulverized fuel ash-cement-sand mixture," Materials and Structures, pp. 1-13, 2013. 

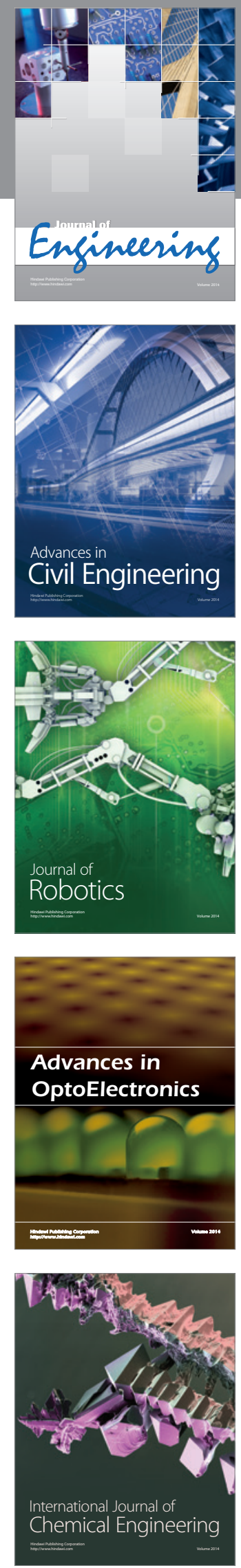

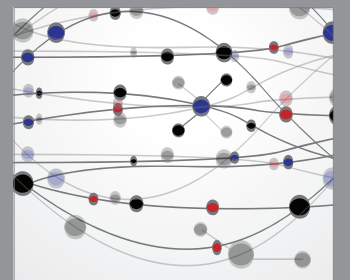

The Scientific World Journal
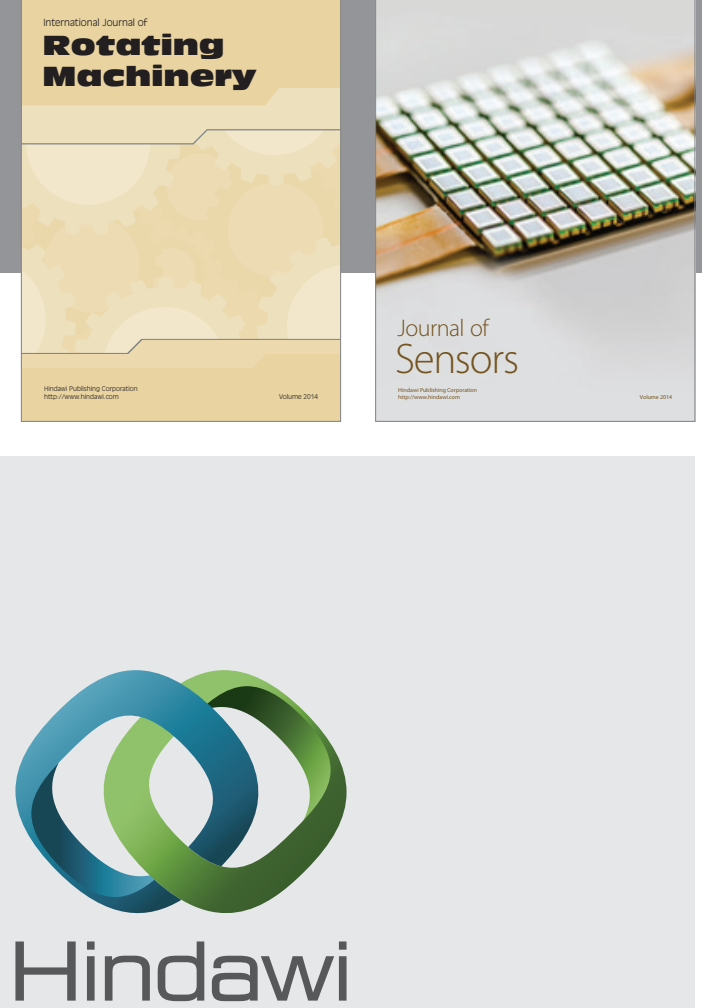

Submit your manuscripts at http://www.hindawi.com
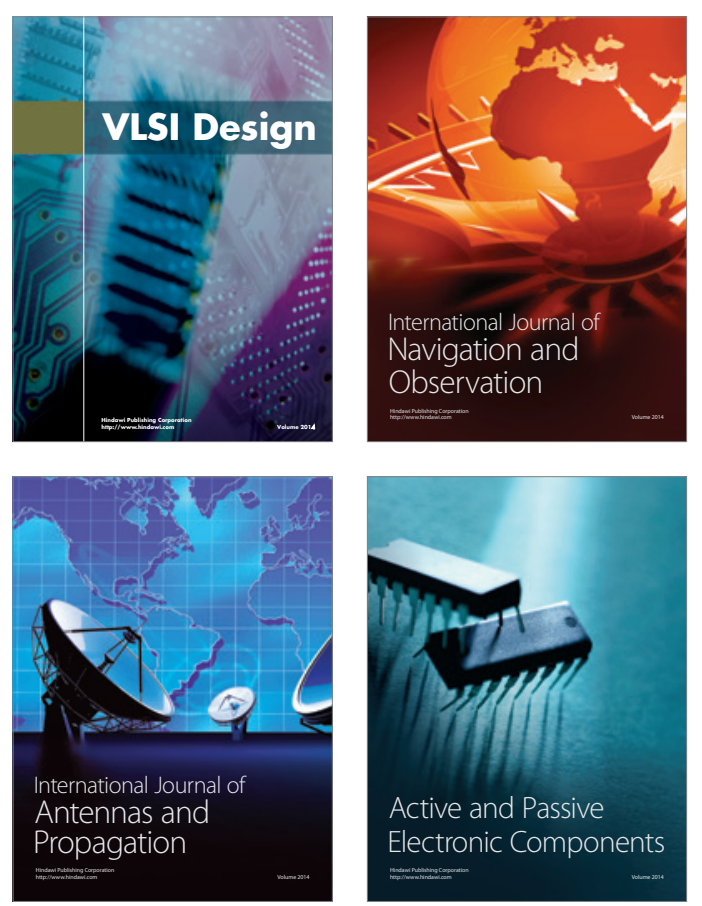
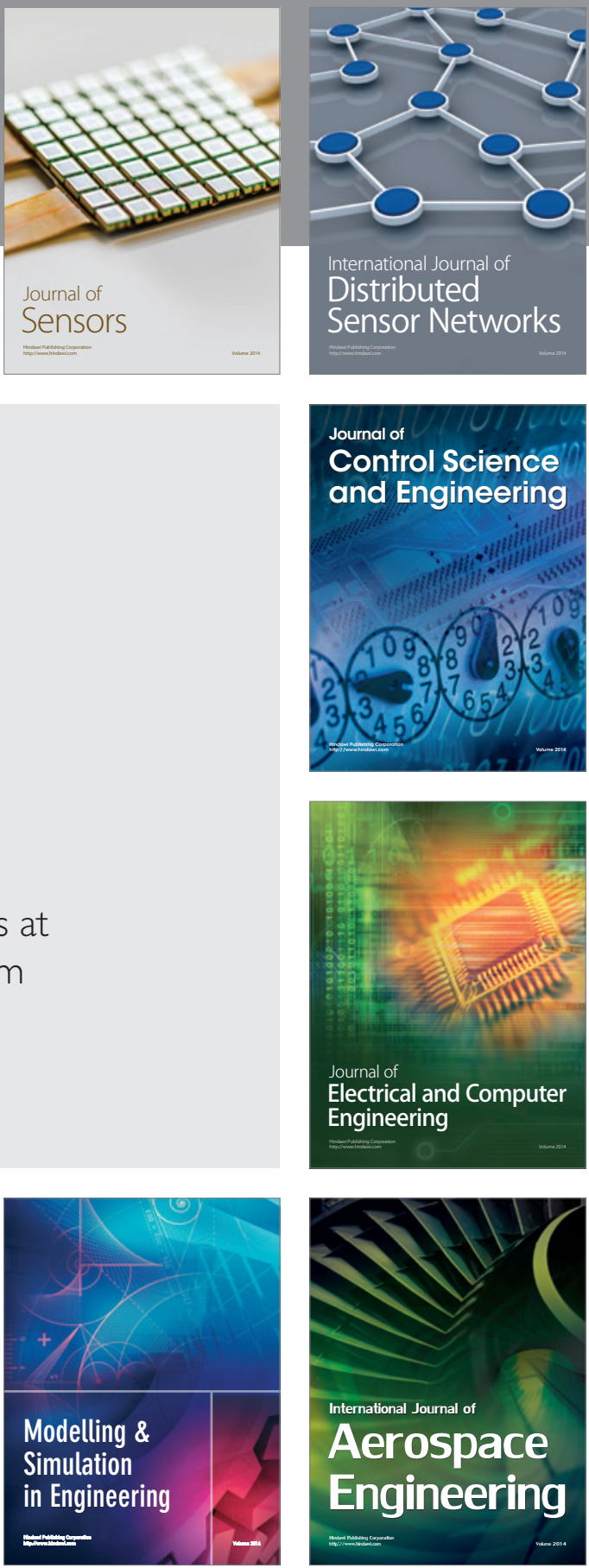

Journal of

Control Science

and Engineering
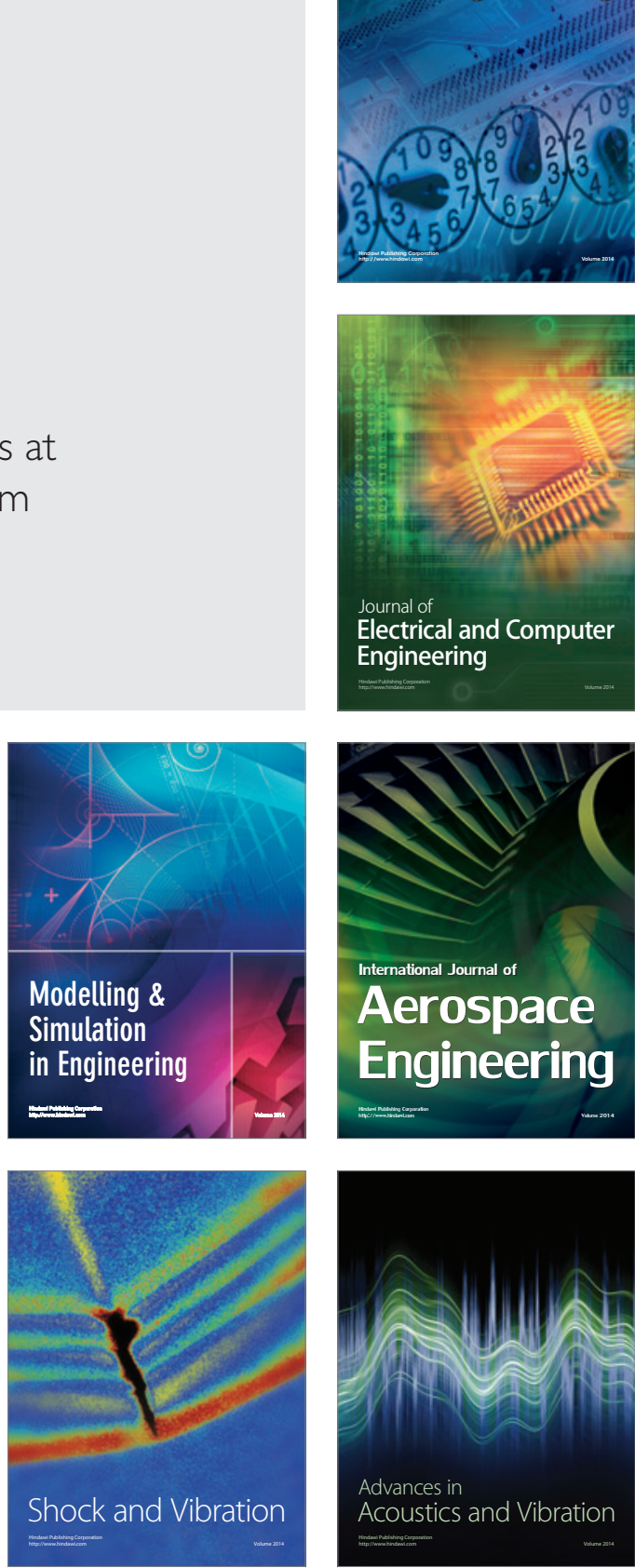